\title{
Effect of nipping at different days in growth and yield of field pea (Pisum Sativum) in mid hills of Nepal
}

\begin{abstract}
Research on effect of nipping at different days in sweet pea (Pisum sativum) was carried out in research field of HASERA Agriculture Research and Training Center, Nepal during winter of 2016/17 with the aim of finding profitable stage of nipping. Total of seven treatments with three replications were laid out in Randomized Complete Block Design. Research was carried out in organic plots using organic practices. Out of seven different treatments applied, (T5) nipping at 30DAS+40DAS gave the best result in yield and nodulation. Nipping at 20DAS, 25DAS, 25DAS+40DAS and 30DAS were at par with both superior treatment (T5) and control treatment (Without nipping). Controlled treatment and nipping at 35DAS gave the inferior results in yield and nodulation. Significant reduction in height was seen in nipped plots than controlled.
\end{abstract}

Keywords: nipping, organic, pea, yield

\author{
Volume 7 Issue 4 - 2017
}

\author{
Bibek Dhital,' Govinda Sharma, ${ }^{2}$ Amit \\ Khanal' \\ 'Department of Agriculture, Institute of Agriculture and Animal \\ Science, Nepal \\ ${ }^{2}$ Hasera Agriculture Research and Training Center, Nepal
}

Correspondence: Bibek Dhital, Department of Agriculture,
Institute of Agriculture and Animal Science, Lamjung Campus,
TU, Nepal,Tel 9843|84697, Email bibekdhital I2@gmail.com

Received:August 19,2017 | Published:September 11,2017

Received: August 19,2017 | Published: September II, 2017

\section{Introduction}

Pea is one of the important grain legumes of Nepal grown as a summer season crop in temperate region and as a winter crop in areas of subtropics Shrestha et al. ${ }^{1}$ It is cultivated in over 25 million acre in the world as a source of human and animal feed NDSU. ${ }^{2}$ It is rich source of protein $(25 \%)$ mostly lysine and tryptophan which is limiting in cereals NDSU. ${ }^{2}$ It also has high sugar content $(12 \%)$, Vitamin A and C, calcium, phosphorus and a little bit of iron NDSU. ${ }^{2}$ Pea contains $86-87 \%$ of total digestible nutrient and containing $5-20 \%$ less trypsin inhibitors than soybean, can be feed to livestock without further processing NDSU. ${ }^{2}$ Not only limited to human and animals but field peas can be used in enhancing the fertility status of soil by using as green manure and as cover crops Papnai et al. ${ }^{3}$ In case of developing country like Nepal, animal source of protein being expensive, plant protein source can be great alternative Bitew et al. ${ }^{4}$ and in context of hilly region, pea accounts for major grain legume crop along with soybean, kidney bean and rice bean Khadka et al. ${ }^{5}$ In the hills, food insecurity is a serious problem and legumes could help mitigate this problem provided their production and productivity is given due emphasis Khadka et al. ${ }^{5}$ Nepal imports Pea worth billion every year from Canada and Australia. It was 1.13billion in 2013/14 Sangam $^{6}$ and 1.73 billion in 2014/15 Sangam. ${ }^{7}$ Till date pea is regarded as minor grain legume in Nepal but its area can be expanded if proper technique in enhancing yield are developed Gharti et al., ${ }^{8}$ Singh and Sophia (2005) mentioned the significance of nipping in enhancing the yield and economic return to farmers. Thompson et al. ${ }^{9}$ The Garden smallholder ${ }^{10}$ also reported the beneficial effect of nipping in growth and yield when done at 8 inches height. According to Singh and Sophia (2005), nipping produced higher yield compared to control treatment and nipping at $30 \mathrm{DAS}$ gave the highest return to farmers.

Plant height, branches, benefit cost ratio was also found highest when nipped at 30 DAS Singh et al. ${ }^{11}$ Nipping is also found as effective technique in encouraging flower production and reducing foliage production Albert, ${ }^{12}$ Floret ${ }^{13}$ reported pinching to produce stronger bush of peas. Primary nipping practice at 4 inch height and secondary nipping practices throughout the season in pea is reported beneficial Dyer. ${ }^{14}$ Other than pea, nipping is found beneficial in Capsicum annum Adinde et al. ${ }^{15}$ Cowpea Reddy, ${ }^{16}$ Pigeonpea Sharma et al. ${ }^{17}$ and Chickpea Baloch. ${ }^{18}$ As nipping in pea is one of the least discussed practices in research field (Singh 2005), this study aims at finding the proper stage of plant growth in terms of DAS for nipping practice in pea so as to maximize production with minimal modification. As nipping practice doesn't require any tools and equipment, it can be a handy and cost effective practice for small farmers as well.

\section{Material and methods}

The experiment was conducted during the winter (rabi) seasons of 2016/17 at the research farm of HASERA Agricultural Research And Training Center, Kavre, Nepal. The farm is certified organic by OCN (Organic Certification Nepal). The experiment was laid out in Randomized Complete Block Design (RCBD) with $2 \mathrm{~m}^{*} 2 \mathrm{~m}$ plot size. Spacing between plots was maintained at $0.5 \mathrm{~m}$ and blocks were maintained at different terrace. Seven treatments, viz. T1, nipping at 20days after sowing (DAS); T2, nipping at 25 DAS; T3, nipping at 25 and 40 DAS; T4, nipping at 30 DAS; T5, nipping at 30 and 40 DAS; T6, nipping at 35 DAS; T7, control (without nipping) were replicated thrice. The variety used was 'arkel', a local variety cultivated in kitchen garden in general and planting geometry was maintained at $25 \mathrm{~cm} * 20 \mathrm{~cm}$. Sowing was done on 20th October. FYM was applied @, $20 \mathrm{ton} / \mathrm{ha}$ i.e. $8 \mathrm{~kg} / \mathrm{plot}$ and additional supplement of $200 \mathrm{ml}$ of cow urine per plant was given at 45 DAS. Weeding was done by light hoeings with kodalo at 35 and 55 DAS to remove weeds. Nipping was carried out by pinching out $4 \mathrm{~cm}$ from the top. In case of secondary nipping, all the secondary branches were pinched $4 \mathrm{~cm}$ from top. Harvesting was done at 10th of March Data analysis was done using statistical tools viz MS Excel and Gen Stat and Duncan's system was used for mean separation.

\section{Results}

\section{Effect on growth}

Nipping has direct impact in growth and branching of pea. Nipping at 30DAS followed by secondary nipping at 40DAS produced significantly higher number of branches and reduced height. Nipping done at 30 DAS and 25DAS+40DAS also produced similar results as done in 30DAS+40DAS. Controlled treatment produced taller plants with lower branches. Nipping at 35 DAS also produced inferior results in branching. Primary nipping at 25-30DAS and secondary at 40DAS was found best for growth of Pisum sativum (Tables 1) (Table 2). All 
treatments were at par in root growth but nipping at 30DAS+40DAS was found significant in nodulation. Controlled treatments reduced the nodulation significantly. T1, T2, T3, T4 and T6 were at par with both $\mathrm{T} 5$ and T7. Thus, Nipping at any days can give better nodulation in pea, but for significant results, nipping at 30DAS followed by secondary nipping at 40DAS was found best.

Table I Effect of nipping at different DAS in height and branching in Pea (Pisum sativum)

\begin{tabular}{|c|c|c|c|c|c|c|}
\hline Treatments & $\begin{array}{l}\text { No of branches } \\
\text { at } 45 \text { DAS }\end{array}$ & $\begin{array}{l}\text { Height }(\mathrm{cm}) \\
\text { at } 45 \text { DAS }\end{array}$ & $\begin{array}{l}\text { No. of branches } \\
\text { at } 60 \text { DAS }\end{array}$ & $\begin{array}{l}\text { Height }(\mathrm{cm}) \\
\text { at } 60 \text { DAS }\end{array}$ & $\begin{array}{l}\text { No. of branches } \\
\text { at } 75 \text { DAS }\end{array}$ & $\begin{array}{l}\text { Height }(\mathrm{cm}) \\
\text { at } 75 \text { DAS }\end{array}$ \\
\hline TI & 4.133 & $11.19 \mathrm{ab}$ & $5.267 a b$ & $20.60 \mathrm{abc}$ & $7.400 \mathrm{~b}$ & $29.13 a b$ \\
\hline $\mathrm{T} 2$ & 4.533 & $12.92 \mathrm{ab}$ & $5.467 a b$ & $21.47 a b$ & $7.800 \mathrm{~b}$ & $31.47 \mathrm{ab}$ \\
\hline T3 & 3.467 & $14.45 \mathrm{a}$ & $6.867 \mathrm{a}$ & 19.93abc & $8.000 \mathrm{ab}$ & $27.93 a b$ \\
\hline T4 & 4.8 & 13.65ab & $5.933 a b$ & 19.53abc & $8.600 \mathrm{ab}$ & $26.53 a b$ \\
\hline T5 & 4.4 & $9.27 b$ & $6.733 a$ & $13.20 \mathrm{c}$ & $9.633 a$ & $27.60 \mathrm{ab}$ \\
\hline T6 & 4.533 & $13.35 \mathrm{ab}$ & $5.867 a b$ & $17.93 \mathrm{bc}$ & $7.333 b$ & $24.40 \mathrm{~b}$ \\
\hline T7 & 4.6 & $15.2 \mathrm{Ia}$ & $4.667 \mathrm{~b}$ & $26.87 \mathrm{a}$ & $7.333 b$ & $35.47 a$ \\
\hline LSD & 1.393 & $4.62^{*}$ & $1.658^{*}$ & $6.942 *$ & $1.676 *$ & $8.073 *$ \\
\hline CV & $9.60 \%$ & $3.90 \%$ & $4.70 \%$ & $13.20 \%$ & $6.20 \%$ & $10.20 \%$ \\
\hline
\end{tabular}

The statistical difference between sample types were analyzed by One-Way ANOVA in randomized block; $*=p<0.05$. Values with a common letter as superscript do not differ as a statistical significance of $p<0.05$ in Duncan's Test.

Table 2 Effect of nipping at different DAS on root growth and nodulation in Pea (Pisum sativum)

\begin{tabular}{lll}
\hline Treatments & $\begin{array}{l}\text { Root depth at } \\
\text { harvest }\end{array}$ & $\begin{array}{l}\text { No of root nodules at } \\
\text { harvest }\end{array}$ \\
\hline T1 & 18 & $9.200 \mathrm{ab}$ \\
T2 & 17.87 & $10.753 \mathrm{ab}$ \\
T3 & 15.63 & $11.133 \mathrm{ab}$ \\
T4 & 17.74 & $8.490 \mathrm{ab}$ \\
T5 & 17.2 & $11.400 \mathrm{a}$ \\
T6 & 16.75 & $10.150 \mathrm{ab}$ \\
T7 & 17.6 & $7.500 \mathrm{~b}$ \\
LSD & 3.084 & 3.375 \\
CV & $4.90 \%$ & $36.30 \%$ \\
\hline
\end{tabular}

The statistical difference between sample types were analyzed by One-Way ANOVA in randomized block; $*=p<0.05$. Values with a common letter as superscript do not differ as a statistical significance of $p<0.05$ in Duncan's Test.

\section{Effect on yield}

Table 3 Nipping at 30 DAS followed by secondary nipping at 40DAS produced significantly higher yield compared to controlled treatment and Nipping at 35 DAS. T1 (Nipping at 20DAS) was at par with both T5 (30DAS +40DAS) and T7 (Controlled). T2 (25DAS), T3 (25DAS+40DAS) and T4 (30DAS) were found at par with T5 (30DAS +40DAS), T6 (35 DAS) and T7 (Controlled). Thus, for best results, nipping at 30DAS followed by 40DAS was found best out of 7 treatments applied.
Table 3 Effect of Nipping at different DAS in Yield and Yield attributes in Pea (Pisum sativum)

\begin{tabular}{llll}
\hline Treatments & $\begin{array}{l}\text { Pods per } \\
\text { plant }\end{array}$ & $\begin{array}{l}\text { Grains per } \\
\text { pod }\end{array}$ & Yield ton/ha \\
\hline TI & $15.6 \mathrm{a}$ & 5.107 & $3.33 \mathrm{ab}$ \\
T2 & $12.27 \mathrm{ab}$ & 5.393 & $2.867 \mathrm{abc}$ \\
T3 & $10.73 \mathrm{ab}$ & 5.267 & $2.533 \mathrm{abc}$ \\
T4 & $10.67 \mathrm{ab}$ & 5.013 & $2.800 \mathrm{abc}$ \\
T5 & $12.13 \mathrm{ab}$ & 4.553 & $3.667 \mathrm{a}$ \\
T6 & $8.67 \mathrm{~b}$ & 5.627 & $2.133 \mathrm{c}$ \\
T7 & $11.73 \mathrm{ab}$ & 5.153 & $2.467 \mathrm{bc}$ \\
LSD & $5.85 *$ & 1.47 & $1.084^{*}$ \\
CV & $5.70 \%$ & $8.30 \%$ & $10.10 \%$ \\
\hline
\end{tabular}

The statistical difference between sample types were analyzed by One-Way ANOVA in randomized block; $*=p<0.05$. Values with a common letter as superscript do not differ as a statistical significance of $p<0.05$ in Duncan's Test.

\section{Discussion}

Singh MS. S. Devi 2005 pioneered research on nipping practice in pea. Singh MS. S. Devi reported significantly superior yield in pea when nipped at 30DAS which is in line with the finding of this research as well. But, Singh MS. S. Devi reported nipping at 35DAS as $2^{\text {nd }}$ best time which was the least preferred time with the finding from this research. As research performed by Singh MS. S. Devi didn't involve secondary nipping practice, our finding still needs more validation from different part of the world. 


\section{Conclusion}

In conclusion, nipping was found significant in enhancing the productivity of pea. Nipping practice done before or at 30days was found to be profitable. Nipping done at 30 DAS followed by secondary nipping at 40DAS gave the best results. As nipping plays significant role in nodulation and branching, nipped plots gave superior results over controlled treatments. But primary nipping practice after 30 days is not recommended.

\section{Acknowledgements}

We would like to offer sincere thanks to HASERA Agriculture Research Center, Volunteers, Authors of reviewed literatures and all individuals involved directly or indirectly in completion of this research.

\section{Conflict of interest}

The author declares no conflict of interest.

\section{References}

1. Shrestha R, Neupane RK, Adhikari NP. Status and future prospects of pulses in Nepal. National Agriculture Research. 2011. p. 3-28.

2. NDSU. Field Pea Production. USA: North Dakota State University; 2003. p. 1-8.

3. Papnai G, Singh NP. Applied Horticulture: Crop Production Technology (Vegetable Crops). India: Uttarakhand Open University; 2011. p. 1-15.

4. Bitew Y, Asargew F, Chakelie G. Evaluation of intra and inter row spacing on the seed yield and yield component of Field pea (Pisum sativum L.). Journal de Afrikana. 2015;2(2):1-15.

5. Khadka R, Paudel MN. Inclusion of grain legumes in rice based systems in the mid-hills of central Nepal. Agronomy Journal of Nepal. 2010;1:61-66.
6. Sangam P. Nepal imported agro products worth Rs 99.34 billion last FY. Nepal; 2014.

7. Sangam P. Agro products top import list. Nepal; 2015.

8. Gharti DB, Darai R, Subedi S, et al. Grain legumes in nepal: present scenario and future prospects. World Journal of Agricultural Research. 2014;2(5):216-222.

9. Thompson W, Morgan J. How to grow sweet peas; 2011.

10. The Garden Smallholder. Pinching out sweet peas; 2011.

11. Singh MS, Devi S. Profitability of nipping in cultivation of pea (Pisum sativum)- an indigenous agro-technique in Manipur. Indian Journal of Agronomy. 2006;51(3):206-208.

12. Albert S. Pea growing problems:Troubleshooting. Harvest to table; 2009.

13. Floret. Flower focus:Growing great sweet peas. Part 2; 2014.

14. Dyer MH, (Eds.), when and why do you pinch back sweet pea.

15. Adinde JO, Uche OJ, Anieke UJ, et al. Effect of nipping on growth and yield of green bell pepper (Capsicum annuum 1. Cv goliath) in iwollo, southeastern nigeria. International journal of science and Nature. 2016;7(2):423-428.

16. Reddy P, Ninganur BT, Chetti MB, et al. Effect of growth retardants and nipping on chlorophyll content, nitrate reductase activity, seed protein content and yield in cowpea (Vigna unguiculata L.). Karnataka J Agric Sci. 2009;22(2):289-292.

17. Sharma A, Potdar MP, Pujari BT, et al. Studies on response of pigeon pea to canopy modification and plant geomtry. Karnataka J Agric Sci. 2003;16(1):1-3.

18. Baloch MS, Zubair M. Effect of nipping on growth and yield of chickpea. The Journal of Animal and Plant Sciences. 2010;20(3):1018-7081. 